\title{
Role of Teachers as Motivators in Learning Islamic Religious Education in Elementary School of Negeri 05 Pontianak Timur
}

\author{
Rianawati $^{1 a^{*}}$, Diah Mentari ${ }^{1}$, Ma'ruf $^{1}$ and Nani Tursina ${ }^{1}$ \\ ${ }^{1}$ Institut Agama Islam Negeri (IAIN) Pontianak, Kota Pontianak 78122, Indonesia \\ a irin_ptk@ymail.com \\ ${ }^{*}$ Corresponding Author \\ Whatsapp Number [082148263025]
}

How to Cite: Rianawati, R., Mentari, D., Ma'ruf, M., Tursina, N. (2020). Role of Teacher as Motivator in Learning Islamic Religious Education in Elementary School of Negeri 05 Pontianak Timur. International Journal for Educational and Vocational Studies, 2(5), 501-509. DOI: https://doi.org/10.29103/ijevs.v2i5.2460

\section{ARTICLE HISTORY}

Received: 15 February 2020

Revised: 21 April 2020

Accepted: 7 May 2020

\section{KEYWORDS}

Teacher Role;

Giving;

Learning Motivation;

Intrinsic;

Extrinsic;

PAI Lessons;

\begin{abstract}
Motivation is the self-driving power of students to learn on an ongoing basis. Furthermore, motivation has a particular position to achieve goals. Therefore, without motivation, the learning process will not go well. Nowadays, often the social environment and the development of modern life affect student learning motivation. Because of that, the optimal role of the teacher is needed to foster student learning motivation. This study aims to determine 1) The purpose of the teacher as an intrinsic motivator of student learning in Islamic Religious Education Subjects in SD Negeri 05 Timur Pontianak (Elementary Schools). 2) The purpose of the teacher as a motivator for extrinsically learning students in Islamic Religious Education subjects at SD Negeri 05 Timur Pontianak. This type of research is qualitative research. Data collection techniques through in-depth interview techniques and participatory observation techniques. Based on the analysis results, the findings of this study are: 1) The role of the teacher as intrinsic learning motivator in students is done by increasing the desire of students to acquire skills in learning, obtaining information about science, hopes of achievement (academic and non-academic achievements) desire to be the best and hope to be accepted by parents.
\end{abstract}

This is an open access article under the CC-BY-SA license.

\section{INTRODUCTION}

Islamic Religious Education is essential to be carried out to convey knowledge, values, and religious skills in the lives of students. Islamic education aims at students having faith, piety, and noble character. Through Islamic Religious Education, not only do students understand about the Five Pillars of Faith, the Five Pillars of Islam, knowledge about the issue of aqeedah, worship, and morals. then more importantly is the student practice what he learns with the values in Islamic Religious Education namely values religious values, discipline, independent, please help, compassion, love of knowledge, love of peace, empathy, and others.

This is as stipulated in the Law of the Republic of Indonesia No. 20 of 2003 Article 1 paragraph 1 concerning the National Education System which states that Education is a conscious and planned effort to create an atmosphere of learning and learning process so that students actively develop their potential to have moral, spiritual strength, self-control, personality, intelligence, account noble, and the skills needed by himself, society, nation, and country.
However, in the empirical facts that occur at this time, the learning motivation of students is felt to decrease towards the learning of Islam. As explained by Rianawati (2014: 376) that the implementation of Islamic religious education has many disadvantages, including that Islamic religious education in educational institutions prioritizes the transfer of knowledge rather than the values of Islamic religious education, so it is not surprising if students have report cards that are good but inversely proportional to its character. Besides, Islamic religious education teachers do not present interesting strategies and learning methods so that Islamic Religious Education learning seems monotonous and boring. This is one of the reasons for the lack of motivation to study Islamic Religious Education in schools.

Besides, what causes students' motivation to learn is the difficulty of students in understanding the material of Islamic Religious Education because Islamic Religious Education teachers use traditional teaching methods, so students only passively see and listen to their teacher preach. This causes students to understand and not be able 
to apply the knowledge they receive, and even students become bored in learning (Masropah, 2017).

The optimal role of the teacher in learning is indispensable in growing and increasing student learning motivation, so students are encouraged and eager to learn. Manizar (2015) said that the teacher as a learning motivator must create an atmosphere of learning that is interesting, fun and a sense of security in students by being open to students, helping students in overcoming learning difficulties, creating harmonious relationships with students, always encouraging students to achievers in learning and encourages students to be active in learning.

According to Law No. 20 of 2003 and Law No. 14 of 2005, the role of teachers is as educators, instructors, mentors, directors, trainers, assessors, and evaluators of students. The role of the teacher as a learning agent serves to improve the quality of education. The role of teachers as agents of learning in improving the quality of education through improving the quality of learning, among others, as a facilitator, motivator, motivator, learning engineer and learning inspiration for students (Article 4 of Law No. 14/2005).

According to Sardiman (2012), the teacher's role as a motivator is significant for increasing the excitement and development of student learning activities. Teachers must be able to provide stimulation and provide encouragement and reinforcement to dynamize students' potential to foster activity and creativity so that there will be dynamics in the teaching and learning process. As a motivator, the teacher is obliged to increase student motivation. According to Kartono (1985), motivation is a condition that causes or gives rise to specific behaviors that give direction and resilience to certain behaviors. The highest motivation is reflected in the perseverance that is not easily broken even though it is plagued by many difficulties faced in order to achieve success, which is its goals and ideals. Learning is an effort to change behavior with a series of activities such as reading, listening, observing, and imitating, and so on. A person learns by interacting with his environment in order to change behavior.

Learning motivation is a driving force from within individuals to conduct learning activities to increase skills and knowledge and experience. This motivation grows because of the desire to be able to know and understand something that encourages and directs students' learning interest so that they are genuinely in their learning. Learning motivation is an essential factor because it is a condition that encourages students to do learning (Walgito, 1995).

The teacher, as a motivator, means the teacher as a motivator for students in order to increase the excitement and development of student learning activities. It often happens students who lack achievement, this is not due to having the low ability, but due to the lack of motivation to learn from students so that he does not try to exert all his abilities. In such cases, the teacher, as a motivator, must know the motives that cause low student learning power that causes a decrease in learning achievement. The teacher must stimulate and provide encouragement and reinforcement to revive the enthusiasm and enthusiasm of student learning.

Based on the results of preliminary observations, SD Negeri 05, in grade III, many of these children lack enthusiasm in learning, students' encouragement to listen to explanations and do assignments in class is still relatively low. Student learning activities are still more dominant in listening and taking notes, and learning interactions in the classroom are still one-way between students and teachers. The low motivation to learn students is due to the lack of the role of parents in motivating their children. To study Islamic Religious Education subjects, the lack of facilities that support the learning process such as learning media, the condition of the school environment and the presentation of learning that is still conventional with a more teacher-oriented learning process so that students are more passive and only accept what the teacher is lecturing.

Students seem less structured to think critically to solve problems, understand material concepts, and understand educational values. Because of the low motivation of students to learn that ultimately also affect the learning outcomes obtained by students. This can be seen from each of the final tests, and it turns out that more than $60 \%$ of students' scores have not yet reached the minimum completeness criteria (KKM) which standardize 75.00 , and there are only a few students whose grades are complete or reach the minimum completeness criteria (KKM).

As for the causes to overcome these problems, several attempts have been made by teachers to increase student motivation by utilizing the facilities available at school and continue to empower the full potential of students. PAI teachers also provide encouragement and advice so that students are always eager to learn Aama because religion is a way of life for Muslims. With the problems that the researchers have described above, the researcher is interested in researching the role of the teacher in motivating learning for students in Islamic Religious Education Subjects at SD Negeri 05 Pontianak Timur.

The reason for choosing the Timur Pontianak 05 public elementary school is one of the schools located on Jalan Tanjung Raya 1, of which around $40 \%$ of elementary school children are from the Beting Permai area. Which area is famous for stigma; for example, Drugs and other criminal acts such as stealing, robbing, drinking, and so on. However, in reality, not all people involved in criminal acts live here. Because there are still many of them, who are not happy about bad things, this study needs to be discussed because the location of this research is SD N 05 Pontianak Timur during an environment prone to detrimental influences on their children.

\section{The Role of Teachers as Motivators}

Implementation of the learning process well, and achieving goals well is also determined by one of them is 
student motivation. If some students lack the right motivation to learn, then it is inevitable that learning goals will not be adequately achieved. Teachers play a significant role in growing and increasing student motivation.

According to Sardiman (2012), the teacher's role as a motivator is significant in order to increase the excitement and development of student learning activities. Teachers must be able to provide stimulation and provide encouragement and reinforcement to dynamize students' potential to foster activity and creativity so that there will be dynamics in the teaching and learning process.

Besides, according to Mulyasa (2007; 2011) as a motivator, the teacher must generate student learning motivation, taking into account the following principles: a) Students will work hard if they have interest and attention to their work; b) Provide clear and understandable tasks; c) Give appreciation for the work and achievements of students; d) Provide a fair and transparent assessment.

More specifically Senjaya (2008) below suggests some general guidelines for teachers in order to increase student motivation such as clarifying goals to be achieved, arousing student interest, creating a pleasant atmosphere in learning, giving generous praise for each student's success, giving assessment, comment on the results of student work and create competition and cooperation. For more details about the teacher's role as a motivator, as revealed by Senjaya (2008) can be explained as follows:

\section{Clarify the Goals to Be Achieved}

\section{Generating Student Interest}

Students will be encouraged to learn when they have an interest in learning. Several ways can be done to arouse students' interest in learning, including: a) Link the material to be taught with the needs of students. Student interest will grow when he can catch that the subject matter is useful for his life. Thus the teacher needs to explain the relationship of subject matter with the needs of students; b) Adjust the subject matter to the level of experience and ability of students. Lesson material that is too difficult to learn or subject matter that is far from student experience will not be of interest to students. The subject matter that is too difficult will not be able to be appropriately followed, which can cause students to fail to achieve optimal results, and failure can kill students' interest in learning. Usually, the student's interest will grow if he gets success in learning; c)Use a variety of models and learning strategies, such as discussion, group work, experiments, demonstrations, and so on.

\section{Create a Fun Atmosphere in Learning}

Students may only be able to study well when there is a pleasant atmosphere, feel safe, free from fear. Try to keep the class forever alive and fresh, free from tension. For this reason, the teacher can occasionally do funny things.

\section{Give a Fair Compliment to Every Student's Success}

Motivation will grow when students feel valued. Giving generous praise is one of the ways that can give awards. Praise does not always have to be with words.
Praise and appreciation can be done with gestures, such as a proper smile and nod, or maybe with a convincing look in the eyes.

\section{Give Rating}

Many students study because they want to get good grades. For that, they study hard. For some students, grades can be a powerful motivation for learning. Therefore, the assessment must be done immediately so that students know the results of their work as soon as possible. Assessment must be done objectively according to the ability of each student.

\section{Give Comments on Student Work Results}

Students need appreciation. Appreciation can be done by giving positive comments. After students finish working on an assignment, it is best to comment immediately, for example, by writing "good" or "continue your work" and so on. Positive comments can increase student motivation.

\section{Create Competition and Cooperation}

Healthy competition can have a good influence on the success of student learning processes. Through competition, students may try hard to get the best results. Therefore, the teacher must design learning that allows students to compete for both between groups and between individuals. However, it is recognized that competition is not always beneficial, especially for students who are perceived to be unable to compete. Therefore the cooperative learning approach can be considered to create competition between groups.

Based on some instructions on how to arouse students' motivation to learn above, motivation can sometimes be raised by other negative ways such as giving punishment, reprimand, and criticism, giving a slightly bulky (challenging) task. However, such techniques can only be used in some instances. Some experts say that generating motivation in such ways is more detrimental to students. Hence, if it is still possible in positive ways, it should be encouraged to avoid negative motivation.

\section{Student's motivation to study}

According to Rianawati (2020), motivation is encouragement, a conscious effort to influence a person's behavior so that he is moved to act to do something to achieve precise results or goals. Meanwhile, according to Ahmadi (2005), motivation is a psychological condition that drives people to do something (Journal of Automotive Engineering Education, Muhammadiyah University, Purworejo). Another case with Suryabrata (2001) explains that motivation is a psychological condition that drives a person to do something. So the motivation to learn is a psychological condition that encourages learning.

Based on some of the opinions expressed that can be explained, motivation is an attempt to provide psychological conditions that encourage students to learn. The learning motivation of each student is different. This difference causes differences in attitudes, behavior, and the role of students in their position as subjects in learning. Therefore, in learning, the teacher acts as a motivator, motivator, and 
facilitator to foster positive motives in students. Parents are no less important as a guide to motivate learning while at home. Likewise, the environment in which he lives will contribute to encouraging Muris to study.

In the process of learning, motivation is the initial stage that must be raised because without motivation, and students do not want to learn. According to Daradjat (2004), motivation has several functions, including: 1) Encourages and activates students to remain interested and alert; 2) We are focusing the child's attention on specific tasks related to the achievement of learning goals; 3) Help meet the need for short-term results and long-term results.

While the motivational function, according to Sardiman (2012), is as follows: a) Encourage humans to do. Motivation, in this case, is the driving force of every activity undertaken; b) Determine the direction of the action, namely towards the goal to be achieved; thus, motivation can provide direction and activities that must be done in accordance with the formulation of the goal; c) Selecting the action, which determines what actions must be done in harmony to achieve the goal, by setting aside actions that are not useful for the purpose.

Based on the above opinion, it can be understood that parents' motivational function is to encourage their children to learn, guide, and direct children's learning in the direction they want to achieve. Motivation can generally be divided into two points of view, namely, the motivation that comes from within a person (intrinsic motivation) and motivation that comes from outside oneself (extrinsic motivation). Intrinsic motivation is the motives that become active or functioning and do not need to be stimulated from the outside because each self has the urge to do something (Djamarah, 2002).

Based on the opinion above, it can be understood that there are two types of motivation, namely motivation that comes from within students and motivation that comes from outside students. According to Suryabrata (2001), motivation, when viewed from the source, is divided into two parts, namely intrinsic motivation and extrinsic motivation. The description of intrinsic and extrinsic motivation can be described as multiple:

\section{1) Intrinsic Motivation}

According to Suryabrata (2001), intrinsic motivation is the motivation that functions without being stimulated from the outside. This intrinsic motivation arises because there is an awareness in a person, such as the emergence of interest, physical condition, and the emergence of feelings of pleasure doing an activity. Similar also expressed by Yamin (2008) that what is meant by intrinsic motivation is that learning activities begin and continue, based on appreciation something absolutely necessary and urgently related to learning activities.

According to Djamarah (2002), the intrinsic motivation that is motives that become active or functioning do not require external stimulation, because, in every individual, there is an urge to do something. According to Suryabrata (2001), intrinsic motivation arises from within a person due to: a) The desire to acquire individual skills; b) The desire to obtain information; c) The desire to excel; d) The desire to be the best; e) The desire to be accepted by others.

Based on the various opinions above, it can be concluded that the factors that influence intrinsic motivation include one's desire to learn, satisfaction with the results to be obtained, good habits have done at home and at school and self-awareness to change.

\section{2) Extrinsic Motivation}

Extrinsic motivation is also called external motivation, and extrinsic motivation is usually in the form of praise, rewards, competition, and punishment. According to Suryabrata (2001), extrinsic motivation is motives that function if obtained from external stimuli such as the family environment, school environment, and community environment. According to Yamin (2008) said that extrinsic motivation, namely learning activities that grow from a person's impulses and needs, is not related to his learning activities.

\section{MATERIALS AND METHODS}

This research's approach is a qualitative research that is data collected in the form of words, images, not numbers. (Danim, 2002). Creswell (2017) explains that qualitative research, researchers are highly dependent on data in the form of information and observations in the field. Meanwhile, Gay \& Mills (2006) explains that the process in qualitative research collects data, analyzes data, and interprets narratives comprehensively on visual data to gain insight into certain phenomena.

Qualitative data collected are words, language, or conditions of phenomena experienced by the object of research (naturalistic), which are then narrated and interpreted scientifically, systematically, factually and accurately to solve research problems. The location of this research is SD Negeri 05 Pontianak Timur. A research location is a place for research related to the research problem. According to Creswell (2017) that determining the exact location of research will significantly help researchers understand the research problem. This determines the accuracy in choosing respondents to be observed and interviewed and what events are felt by the research object being interviewed and observed.

Sources of data are research subjects that are sources of information, data sources that are primary or secondary. Arikunto (2012) argues that the data's intended source is the subject from which the data was obtained. The subject as a source of data certainly has to have the capacity and competency following the data requirements. Data sources in this study were PAI teachers and students at SD 05 Timur Pontianak.

Data collection techniques were non-participant observation and interviews to find and dig up data about the teacher's role as an intrinsic and extrinsic motivator and the factors that influence it. Observation is an 
observation activity carried out by a researcher. According to Bungin (2009), what is meant by in-depth interviews is the process of obtaining information for research purposes through question and answer while face to face between the interviewer and the informant with or without using interview guidelines. Then the data that has been collected is then analyzed to find the meaning of the data in the form of words to describe the facts in the field. According to Patton (in Moleong, 2017) that data analysis is the process of arranging data sequences, organizing them into a basic pattern, category, and description. The data analysis techniques are data collection, data reduction, data display, and data verification.

\section{RESULTS AND DISCUSSIONS}

Based on the results of interviews and observations carried out, several field facts obtained related to the focus of research on the role of the teacher as a motivator in motivating to learn to third-grade students in PAI Subjects at SD Negeri 05 Timur Pontianak. As for this discussion, the researchers did following the order of the questions research.

\subsection{The Role of Teachers as Motivators in Providing Intrinsic Learning Motivation in Islamic Religious Education}

The teacher's role as a motivator in providing intrinsic learning motivation to students in Islamic Religious Education Subjects at SD Negeri 05 Timur Pontianak is as follows:

\section{a. Desire to Obtain Certain Skills}

Some skills must be mastered by students of 05 Pontianak Timur Elementary School, namely Islamic Religious Education teachers motivate so that students want to acquire the skills of reading and writing the Qur'an in accordance Makharijul Khuruf and basic recitation laws. Islamic Religious Education teachers motivate students by explaining various teachings for people who study the Koran and tell stories of pious people who make the Koran as a protector and guide to their lives, how the Companions diligently and hard work copy and recorded the Koran.

Islamic Religious Education Teachers also motivate so that students want to have the skills of worship, namely by encouraging students by conveying how important worship and the nature of human beings created is to worship. The worship skills that students must master include Mahdah worship, such as purification, prayer, fasting, and Ghairu Mahdah worship, such as charity and other social activities. Furthermore, motivation is also conveyed by the teacher so that students want to acquire good behavior skills by giving examples of good behavior, providing support so that students continue to improve themselves by showing morality.

Islamic Religious Education teachers must provide motivation and enthusiasm to students on an ongoing basis to diligently practice reading, writing, and memorizing the Qur'an following the rules of Tajweed law, diligently worshiping, and familiarizing themselves with noble morals because, without strong motivation, students are lazy to practice to improve their skills which will have a bad effect on students. Moreover, the positive impact of motivating students is that students will have independent character, initiative, active, creative, and innovation in learning. Baron and Donn (in Mussen et al., 1994) explained that students who have high motivation are shown by several characters, such as initiative, diligent and active learning, not easy to satisfy, on time, and discipline, always trying to learn with the best results.

\section{b. Obtaining Information}

Islamic Religious Education teachers motivate and advise students in Timur Pontianak 05 Public Elementary School to seek and obtain information on religious knowledge (Aqeedah morals, al-Qur'an hadith, Islamic jurisprudence, and culture) and general science. (Social Sciences, Natural Sciences, and Mathematics). Islamic Religious Education Teacher.

Motivation to search for, acquire, and develop knowledge must be supported by a learning strategy that is fun, interesting, engenders an attitude of active and creative learning. Therefore, Islamic Religious Education teachers must be able to develop contextual learning materials and methods based on cooperation and creativity. Motivation develops because learning uses methods of innovation, creative and fun, in addition to the ability of teachers to manage and deliver learning materials to determine the success of learning, especially when it comes to student motivation. (Riswanto \& Aryani, 2017).

\section{c. Desire for Achievement}

Teachers of Islamic Education always motivate students to have the desire to achieve academic and non-academic achievement at SD Negeri 05 Timur Pontianak. Motivation is done by teachers by providing support and becoming a facilitator for students who want to improve their performance. Academic achievements that must be achieved by students such as good grades, class champions, Olympic champions, and O2Sn and FLS2SN. Besides, teachers also motivate non-academic achievements by providing support and being a facilitator for students to improve student talent.

Motivation is the driving force in a person to achieve high achievements. Achievement motivation is one of the predictive factors determining student achievement (Erlinda \& Dewi, 2015). Mussen (1994) explains that achievement motivation behavior is persevering in difficult tasks, working hard, and choosing challenging but not too difficult tasks. The desire to excel in academics arises from within a person driven by a sense of moral responsibility and maximum performance for achievement. This motivation should be intrinsic is better motivation because it is driven by the desires and ideals that are owned from within him, not because of factors 
from outside himself.

Teachers can increase achievement motivation with a variety of strategies, as according to Handoko (1992) that ways that can increase motivation are to clarify the goals achieved, integrate the motives already owned, integrate temporary goals that are closer, inform the work achieved, entered into the competition, stimulated the achievement of objectives, and set positive examples

\section{d. Want to be the best}

Islamic Religious Education teachers motivate so that students must have the desire to be the best in the afterlife and the world. If someone is not motivated to get the best, then students will become the losers. Losing humans are people who do not know anything. The way the teacher motivates students is to convey the values of virtue to be the best verbally. Rianawati (2020) explains that teachers can instill ethical values through the transformation of values; educators teach good and bad values to students whose communication is limited to the use of verbal language. Students at this stage have not learned the ability to analyze information obtained in connection with real-life empirically.

Motivation to be the best must be based on desire and determination in yourself so that what is aspired to will be achieved properly. This motivation should also be intrinsic, that according to Suryabrata (2001) intrinsic motivation that is the motivation that arises from within a person because of wanting to be the best, is an ego that arises from within a person, in order to be superior and be the best of others. Intrinsic motivation is motivation driven by interest or pleasure in the task itself and is within the individual rather than relying on external pressure. (Hamid and Mohammad, 2012) mention that intrinsic motivation (IM) refers to involvement in behavior that is inherently satisfying or pleasant. IM is non-instrumental; that is, actions that are intrinsically motivated do not depend on anyone's results can be separated from the behavior itself. (Legault, 2016).

It is not easy for teachers to foster intrinsic motivation in students, other than through oral means, teachers can use the stages of value internalization that is through the stages of value transactions, value transformation, and value internalization. (Rianawati, 2020). At the stage of value internalization, the teacher motivates students always to emulate the exceptional character of the Prophet, as explained in the Word of God in Sura al Ahzab verse 21, namely:

Indeed, the Prophet (s) was a good role model for you (i.e.) for those who hope for (the mercy) of Allah and (coming) on the Day of Resurrection, and He often mentions Allah (al-Ahzab: 21).

\subsection{The Role of the Teacher Provides Extrinsic Motivation to Student in Islamic Education Subject}

The role of the teacher as a motivator in providing extrinsic learning motivation to students in the PAI Subjects of Public Elementary School 05 Timur Pontianak as follows:

\section{a. Learn to Meet Obligations}

PAI teachers provide motivation to arise in 05 Pontianak Timur Elementary School students to learn in order to fulfill their obligations, and the teacher encourages students to continue learning to reach their goals, see their potential and sharpen them to become better. Muslims must learn the science of religion and practice it for the progress of the nation and state.

This motivation can be developed through extrinsic motivation ie. Students are encouraged to learn because it is based on academic motivation in the learning curriculum. If students do not study according to curriculum requirements, students will be left behind in their lessons.

Motivation can be considered a strong involvement in learning and active academic endeavors. According to many authors, academic motivation is positively related to academic achievement, academic performance, and willingness to learn (Pintrich \& Schunk, in Blaskova, 2014).

\section{b. Learn to Avoid Punishment}

Teachers motivate learning to avoid punishment in 05 Pontianak Elementary School in Timur through good advice and telling stories of successful people, so students are motivated to continue learning to avoid punishment and exclusion from parents at home.

Punishment is one of the extrinsic motivations, namely the driving force from outside to do something with a sense of coercion. Students who are lazy to learn will be encouraged to learn when he knows that not learning or not doing assignments is one form of violation of the rules of learning in school. Rianawati \& Nurhamid (2020) explained that giving penalties for violations of school rules (one of which is disorderly in learning) to uphold the character of student discipline is done by verbalizing punishment in Student Orientation Period (student introduction period) (Rianawati \& Nurhamid, 2020).

\section{c. Learn to the Sake of the Presented Material Prize}

The teacher gives a gift once a student has a good grade. The prize is usually a book and other stationery. The teacher aims to give gifts so that other students are also more eager to study more diligently.

The desire to learn to get gifts is an external regulation referring to external behaviors, one of which is gift giving (Deci et al. 1991). However, providing rewards in supporting teaching for intrinsic motivation is an act that is not good in education. Therefore, teachers must be able to present methods to develop intrinsic motivation, such as classroom climate, behavior management, lesson planning, overcoming children's learning disabilities, and presenting teaching methods that are designed especially for these children (Baranek, 1996).

Dembo (1994) proves that students are motivated to participate in an activity with a desire to satisfy themselves, for example, the desire to get approval or peer 
acceptance, mastery, goals (desire to learn and master new knowledge), and performance goals (desire to show one's ability to others by getting good grades or getting higher grades from peers) (Rudhumbu, 2014).

\section{d. Learn to the sake of increasing prestige}

The teacher motivates students not to learn because it increases prestige. The seriousness and desire to learn must be from the ideals to develop the nation and state. Nevertheless, according to the teacher, if the sense of prestige is used as a basis for competing between his peers.

Some students learn based on their sense of prestige to maintain their self-esteem. Usually, students who study because of their sense of prestige come from upper middle-class families. From an anthropological perspective, prestige is the price desire of someone who is rooted in himself so that he is always self-oriented. The community encourages individuals to change who they are to fulfill prestige (Barkow in Campbell, 2019). Psychologists argue that individuals with higher prestige are motivated to compete and excel among peers of higher prestige to maintain the benefits of their status (Henrich \& Gil-White in Campbell, 2019).

\section{e. Learn to the Praise of Others}

The teacher motivates students not to have the desire to get praise in learning. Learning to get compliments is only temporary, so students only want to learn when they get praise and will not learn if there is no praise. Furthermore, the teacher states that students should not be praised often if they manage to get good grades.

Excessive praise of one's success will have a negative impact. Learning because you want to get praise will lead to an attitude of dependence on praise. If students do not receive praise, they will be disappointed, and their learning motivation will decrease. Educators who show excessive love for children will cause an attitude of excessive dependence on personal relationships, making them anxious and uncertain of their abilities. Strong dependence on reward or punishment in the cognitive realm seems to produce excessive competitiveness and competition, so this will negatively affect children (Noel, 1991).

\section{f. Study for Demands}

According to the teacher, there are various kinds of learning motivation in students. One of them is the demands of the students. For example, after learning, students want to be invited by teachers to play quizzes and want to get prizes if they win the quiz. Based on teacher information, parents experience difficulties when inviting their children to study, but if parents promise to meet the demands of children, children want to learn.

Students who are lazy to learn or lack the motivation to learn do not like learning activities. Usually, students want to learn if educators meet their demands. For example, some students demand that their parents buy their favorite toys, so students want to learn. Learning motivation due to demands will have a negative impact on student learning habits. Because students will have a strong dependence on demands. Students will learn if their demands are met.

Extrinsic motivation requires tangible or verbal rewards, so satisfaction comes (Demir, 2011). That is, the behavior is not carried out alone but instead to receive a gift or to avoid punishment (Pelletier, in Demir, 2011). Extrinsic rewards tend to be not good from time to time (Stipek, in Lai, 2011).

To foster student learning motivation, the teacher's role requires more serious teachers. The teacher must take a deep approach involving the intention to achieve a personal understanding of the material presented. This requires living interaction with content, linking it with prior knowledge and experience, examining evidence, and evaluating logical steps to achieve the expected goals (Noel, 1991).

Students who are actively involved with what they learn tend to understand more, learn more, and appreciate the relevance of what they have learned, rather than students who passively accept what the teacher teaches them. As a teacher, therefore, faced with a big challenge, namely how to encourage and enable students to be involved in the learning process (Park, 2003).

\section{CONCLUSION}

Based on the results of the analysis of research data, it can be concluded that the role of the teacher as a motivator in motivating to learn to third-grade students in PAI Subjects in SD Negeri 05 Timur Pontianak is done in two ways, namely providing intrinsic and extrinsic motivation. Specifically research this concludes as follows:

1. The role of the teacher as a motivator in providing intrinsic learning motivation to students in PAI Subjects in Elementary School of Negeri 05 Pontianak Timur is done by increasing the students' desire to acquire skills in learning, obtaining information in the form of science. The desire to excel both academic and non-academic achievements, the desire to be the best, and the desire to be accepted by others both by parents, teachers, and associates.

2. The role of the teacher as a motivator in providing extrinsic learning motivation to students in PAI Subjects in Elementary School of Negeri 05 Pontianak Timur is done by increasing the sense that learning in order to fulfill obligations, learning in order to avoid penalties threatened from parents, teachers and the school, learning to obtain prizes both material and non-material, learn to increase prestige both to relatives and to friends, learn to get praise from parents, teachers, and friends and learn for demands. 


\section{REFERENCES}

Ahmadi, A. (2003). Psikologi Sosial. Jakarta. Rineka Cipta.

Arikunto, S. (2012). Prosedur Penelitian Suatu Pendekatan Praktis. Jakarta: PT. Reneka Cipta.

Baranek, L. B. (1996). The Effect of Reward and Motivation on Student Achievement. Grand Valley State University Scholar Works (GVSU).

Blaskova, M. (2014). Influencing Academic Motivation, Responsibility and Creativity. Procedia: Social and Behavioral Science. 159 (2014).

Bungin, B. (2009). Penelitian Kualitatif. Jakarta: Kencana Prenada Media Group

Campbell, C. M. dkk. (2019). Prestige or Education: College Teaching and Rigor of Courses in Prestigious and Non-Prestigious Institutions in The U.S. National Academy of Education/Spencer Foundation fellowship.

Creswell, J. (2017). Reseach Design. Pendekatan Metode Kualitatif, Kuantitatif, dan Campuran Edisi Terjemahan. Yogyakarta: Pustaka Pelajar.

Danim, S. (2002). Menjadi Peneliti Kualitatif Rancangan Metodologi, Presentasi, dan Publikasi Hasil Penelitian untuk Mahasiswa dan Penelitian Pemula Bidang Ilmu Sosial, Pendidikan dan Humaniora. Bandung: Remaja Rosdakarya.

Daradjat, Z. (2003). Metodik Khusus Pengajaran agama Islam. Jakarta. Bumi Aksara.

Deci, E. L., dkk. (1991). Motivation and Education : The Self-Determination Perspective. Educational Psychologist. Educational Lawrence Erlbaum Associattes, Inc.

Demir, K. (2011). Teachers' Intrinsic And Extrinsic Motivation As Predictors of Student Engagement. E-Journal of New World Science Academy. Vol. 6, No. 2, 2011.

Depdiknas RI. (2003). Undang-Undang RI No. 20 Tahun 2003 Tentang Sistem Pendidikan Nasional. Jakarta; Depdiknas.

Djamarah, S. B. (2002). Guru dan Anak Didik Dalam Interaksi Edukatif, Suatu Pendekatan Teoritis Psikologis. Jakarta: Rineka Cipta.

Erlinda, R., \& Dewi, S. R. (2015). Achievement Motivation and Academic Achievement Differencesof English Student. Jurnal Ta'dib Volume 18 No.1 (2015).

Gay, L. R., \& Mills, G.E. (2006). Educational Reseach (Competencies for Analysis and Application). USA: Pearson.

Hamid, T., \& Mohammad, M. J. (2012). The Effect of Motivation in Education. Journal Procedia: Social and Behavior Sciences. 31 (2012).

Handoko, M. (1992). Motivasi Daya Penggerak Tingkah Laku. Jakarta: Rineka Cipta

Kartono, K. (1985). Bimbingan Belajar dan Kesulitan-kesulitan Belajar. Bandung: Tersito.
Lai, E. R. (2011). Motivation: A Literature Review. Reseach Report. Retrieved from: https://images.pearsonassessments.com/images/tmrs/M otivation_Review_final.pdf

Legault, L. (2016). Intrinsic and Extrinsix Motivation. V.Zeigler-Hill, T.K. Shackelford (eds.), Encyclopedia of Personality and Individual Differences. Springer International Publishing AG.

Manizar, E. (2015). Peran Guru Sebagai Motivator Dalam Belajar. Jurnal Tadrib. Vol.1, No. 2 Desember 2015.

Masropah, S. T. (2017). Peningkatan Motivasi Belajar Siswa Mata Pelajaran PAI Melalui Metode STAD. Briliant: Jurnal Riset dan Konseptual. Vol. 2, No. 2, Mei 2017.

Moleong, J. L. (2017). Metodologi Penelitian Kualitatif. Bandung: PT. Remaja Rosda Karya

Mulyasa, E. (2007). Menjadi Guru Profesional. Jakarta: Gramedia.

Mulyasa, E. (2011). Menjadi Guru Frofesional. Bandung: Remaja Rosdakarya.

Mussen, P. H. dkk. (1994). Perkembangan dan Kepribadian Anak. Jilid I. Jakarta: PT. Gebra Aksara

Noel, E. (1991). Motivation And Learning Strategies. Paper Presented at The British Psychological Society Education Section Conference in Blackpool, April 1991.

Park, C. (2003). Engaging Students in the Learning Process: the learning Journal. Journal of Geography in Higher Education. Vol.27, No. 2 July 2003.

Ramli. (2014). The Effect of Learning Motivation on Student's Productive Competencies in Voctional High School West Sumatra. International Journal of Asia Social Science. Vol. 4, No. 6. 2014.

Rianawati \& Nurhamid. (2020). The Giving Punishment of School Rules Violation in Enforcing Discipline Characters on MTs. Raudlatussa'adah Pontianak. International Journal for Educational and Vocational Studies. Vol 2. No. 2 (2020).

Rianawati. (2014). Implementasi Model Pembelajaran Kontekstual Berbasis Akhlak Kemandirian. Analisis: Jurnal Studi KeIslaman. Vol. 14, No.r 2, Desember 2014.

Rianawati. (2020). Internalisation of Student Learning: Transformation Process, Transaction and Trans-internalisation of Value in Islamic Education Subject. International Journal of Innovation, Creatifity and Change. Vol. 10, Issue 1, 2020.

Riswanto, A., \& Aryani, S. (2017). Leraning Motivation and Student Achievement: Description Analiysis and Relationships Both. Couns-Edu. The International Journal of Counseling and Education. Vol.2 No.1, March 2017.

Rudhumbu, N. (2014). Motivational Strategis In The Teaching Of Primary School Mathematics In Zimbabwe. International Journal of Education Learning and Development UK. Vol. 2 No.2. 
Sardiman, A. M. (2012). Interaksi Dan Motivasi Belajar. Yogyakarta. PT. Raja Grafindo Persada.

Senjaya, W. (2008). Strategi Pembelajaran; Berorientasi Standar Proses Pendidikan. Jakarta: Kencana Prenada Media Group.

Suryabrata, S. (2001). Psikologi Pendidikan. Jakarta: CV. Rajawali.

Walgito, B. (1995). Pengantar Psikologi Umum. Yogyakarta: Andi.

Yamin, M. (2008). Sertifikasi Keguruan di Indonesia. Bandung: Sinar Baru. 